\title{
Saffron Cultivation in Marginal Alpine Environments: How AMF Inoculation Modulates Yield and Bioactive Compounds
}

\author{
Matteo Caser ${ }^{1}$, Íris Marisa Maxaieie Victorino ${ }^{2,3,4}$, Sonia Demasi ${ }^{1}{ }^{(0)}$, Andrea Berruti ${ }^{2}$, \\ Dario Donno ${ }^{1} \mathbb{D}$, Erica Lumini ${ }^{2}$, Valeria Bianciotto ${ }^{2}$ and Valentina Scariot ${ }^{1, *}$ \\ 1 Department of Agricultural, Forest and Food Sciences, University of Torino, Largo Paolo Braccini 2, \\ 10095 Grugliasco, Italy; matteo.caser@unito.it (M.C.); sonia.demasi@unito.it (S.D.); \\ dario.donno@unito.it (D.D.) \\ 2 Institute for Sustainable Plant Protection, National Research Council (CNR), Viale Mattioli 25, 10125 Torino, \\ Italy; irisvictorino@gmail.com (Í.M.M.V.); berruti.andrea@gmail.com (A.B.); erica.lumini@unito.it (E.L.); \\ valeria.bianciotto@ipsp.cnr.it (V.B.) \\ 3 Department of Life Sciences and Systems Biology, University of Turin, Viale Mattioli 25, 10125 Torino, Italy \\ 4 Biological Science Department, Science Faculty, Eduardo Mondlane University (UEM), Av. Julius \\ Nyerere-Campus Universitário, Maputo 3453, Mozambique \\ * Correspondence: valentina.scariot@unito.it; Tel.: +39-011-670-8932
}

Received: 3 December 2018; Accepted: 30 December 2018; Published: 31 December 2018

\begin{abstract}
Arbuscular mycorrhizal fungi (AMF) establish mutualistic symbiotic associations with plant roots and act as biofertilizers by enhancing plant nutrient and water uptake. Moreover, AMF colonization may influence the biosynthesis of plant bioactive compounds in medicinal and aromatic plants. There is limited information on AMF associations with Crocus sativus L. (saffron) roots and their effect on crop performances and spice quality. In the present work we verified the efficiency of root mycorrhization in potted conditions, and then we evaluated the yield and quality of the saffron produced in two Alpine sites during two cultivation cycles with the application of AMF. Two inocula were applied, either a single-species (Rhizophagus intraradices) or a multispecies mixture ( $R$. intraradices and Funneliformis mosseae). The trial conducted in potted conditions confirmed that both AMF commercial inocula established symbiotic relationships with saffron roots. The multispecies inoculation yielded the highest content of arbuscules in colonized portions of the root $(100 \%)$, while the single-species was slightly less $(82.9 \%)$ and no AMF were recorded in untreated control corms. In open-field conditions, AMF colonization of the root systems, flower production, and saffron yields were monitored, and bioactive compounds contents and antioxidant activity in the dried spice were analyzed using spectrophotometry and high performance liquid chromatography. Overall, the saffron produced was high quality (ISO category) and had high contents of bioactive compounds, with very high total polyphenol content and elevated antioxidant activity. The use of arbuscular mycorrhizal symbionts as biostimulants positively affected saffron cultivation, improving the crop performances and the content of important nutraceutical compounds. In particular, the inoculum composed by $R$. intraradices and F. mosseae increased flower production and the saffron yield. $R$. intraradices alone enhanced the spice antioxidant activity and the content of bioactive compounds such as picrocrocin, crocin II, and quercitrin. Since saffron is the world's highest priced spice, the increases in yield and quality obtained using AMF suggests that farms in marginal areas such as alpine sites can increase profitability by inoculating saffron fields with arbuscular mycorrhiza.
\end{abstract}

Keywords: Crocus sativus L.; biofertilization; arbuscular mycorrhizal fungi; antioxidant activity; crocin; picrocrocin; polyphenols; safranal 


\section{Introduction}

Saffron (Crocus sativus L.) is a triploid herbaceous geophyte that is reproduced by means of replacement corms and is cultivated in environments with very different soil characteristics [1-3] for its red scarlet stigmas that are used worldwide as a spice and natural dye [4]. Origin, abiotic stresses, agronomical practices, and processing methods (stigma separation, drying, and storage) can influence both the plant and the saffron spice yield, composition, and quality $[5,6]$. The spice's organoleptic properties are ascribed to the relative percentage of peculiar secondary metabolites-crocin, picrocrocin, and safranal-which provide the unique color, bitter taste, and aroma, respectively. The concentrations of these constituents combine to determine the saffron spice quality, as defined by the International Organization for Standardization [7]. Studies related to saffron quality are expanding mainly due to the antioxidant properties of this spice and their positive influence on human health [8]. Antitumor and cancer-preventive properties are mainly attributed to the high carotenoids content [9].

Reproductive, vegetative, and dormancy are the main phenological stages [10]. Saffron flower induction is a very complicated mechanism directly related to ecological conditions and field management $[11,12]$. As in most geophyte plants, both seasonal and daily thermoperiodism are involved as the main environmental factors [11]. Flower induction requires an incubation of the corms at high temperature $\left(23-27^{\circ} \mathrm{C}\right)$, followed by a period of exposure at moderately low temperature $\left(17^{\circ} \mathrm{C}\right)$ for flower emergence. In Mediterranean environments, flower induction occurs from early spring to mid summer, while flower emergence occurs from early- to late-autumn. Differences in the time required for flower initiation have mostly been attributed to the corm size [13]. In addition, Molina et al. [14] reported that air and soil temperatures might be responsible for differential flower induction and duration of up to two months. Flowering is followed by a vegetative stage throughout the winter and formation of replacement corms at the base of shoots. At the end of spring, the leaves reach the highest length, start to senesce, and wither, and the bulbs go into dormancy [14].

Due to its unique biological, physiological, and agronomic traits, saffron is able to exploit marginal land and is included in low-input cropping systems, even if high amount of skilled labour is required [11]. In Italy, saffron cultivation is gaining increasing attention as an alternative crop for sustainable agriculture systems $[11,15]$, where it could represent a valid mean for increasing incomes of multifunctional farms, with a positive impact on the recovery and economy of these areas $[15,16]$. Since saffron is the world's highest-priced spice due to the intensive hand labour required for daily flower picking and stigma separation [14], small increases in the yield and/or quality can connote a large increase in profitability. In this context, the adoption of sustainable cultivation techniques such as the use of biostimulants may represent further help in both the increase in spice yield and active ingredients accumulation [17].

Recent research has focused on the benefits of soil organisms to crops, especially to promote plant nutrient uptake and assimilation [18,19]. Indeed the soil is not only the location of plant life cycle stages, but also the main reservoir for a wide range of plant biostimulants (PBs), including arbuscular mycorrhizal fungi (AMF) [19-21]. Ubiquitous and abundant, AMF are obligate endosymbionts living inside most plant roots present in diverse environments, including productive agricultural systems [22-25]. When colonizing roots, hyphae extend root limits, improving water and inorganic nutrient acquisition from the soil, mainly phosphorus $(\mathrm{P})$ and other minerals, in exchange for photosynthetic products. The use of AMF has a demonstrated economic impact on agriculture and horticulture and they may also confer pathogen protection by altering plant physiological parameters, and improving soil nutrition and aggregation under different growing conditions [26-28].

Mounting evidence indicates that AMF may induce changes in primary and secondary metabolism of host plants, increasing polyphenols, flavonoids, and phytohormone dynamics [29,30]. Such metabolic changes may be ascribed to a transient activation of host defence reactions in colonized roots [20,31]. The role of AMF symbiosis in flowering date and flower production is fragmented [32].

In medicinal and aromatic plants (MAPs), such as Arnica montana L., Coriandrum sativum L., and Anethum graveolens L., AMF colonization influenced bioactive compound biosynthesis such 
as ascorbic acid, flavonoids, polyphenols, carotenoids, and vitamins [33-36]. Inoculation with Funneliformis mosseae Gerd. \& Trappe and G. versiforme P. Karst. improved plant growth and enhanced the glycyrrhizin concentration in Glycyrrhiza uralensis Fisch plants [26]. Moreover, under low P availability, a mix of AMF increased the production of root biomass and of pseudohypericin and hypericin content in flowers of Hypericum perforatum L. [32]. Although widely applied, evidence for AMF symbiosis efficacy and persistence is scant, incomplete, or lacking $[37,38]$ and the use of AMF in crop production is facing some limitations due to product costs, producer awareness levels, and variability in mycorrhizal inoculum quality [21,27]. Many factors can affect the success of inoculation and AMF persistence, including environmental and cultivation conditions, species compatibility, degree of spatial competition with other soil organisms, and the time of inoculation. However, once AMF inoculation is restored and well established in soil, the AMF community will persist through time. If detrimental practices are minimized before and after cultivation, biodiverse mycorrhizal hyphal networks will remain unaltered and infective in the field [27]. Hence, it is important to assess the effects of AMF on crop traits both as early application and as residual persistence in the following crop cultivation seasons.

Incidence of AMF, alone or in combination with plant growth promoting bacteria (PGPB), was reported in corms of C. sativus [39-44]. Different authors report that well-established AMF colonization of saffron roots results in increased corm P content, chlorophyll, fresh and dry corm mass, and leaf matter, and greater soil $\mathrm{P}$ and nitrogen assimilation [43-45]. Shajari et al. [44] indicated a significant effect of AMF in corm growth and mineral assimilation during the second cultivation season, supporting their effective residual effects in saffron cultivation. However, little is known about the effects of AMF on spice yield, and phytochemical profiles in open field cultivation [46,47].

The possibility that AMF can enhance the economic value of saffron by increasing yield and quality is even more interesting if we consider the worldwide increase in use of biocompounds in the food and pharmaceutical industries. Thus, the aims of the present study were (1) to preliminarily verify the constitutive association of AMF with saffron roots in sterile pot conditions, and (2) to assess the AMF symbiosis in open field conditions and its effects on saffron plant growth, productivity, and bioactive compounds content in Alpine open field conditions.

\section{Materials and Methods}

\subsection{AMF Inoculation in Pot}

Saffron corms with horizontal diameters of 1.3 to $2.8 \mathrm{~cm}$ were sown in pots ( $4 \mathrm{~L} ; 1$ corm per pot) in the last ten days of August 2016. Pots were filled with sterile quartz sand (3 L per pot) on a layer of sterilized expanded clay (1 L per pot). Corms were treated with two inocula (MycAgro Lab, Breteniére, FR), one composed of a single fungus Rhizophagus intraradices (Ri) and one of $R$. intraradices and Funneliformis mosseae $(\mathrm{Ri}+\mathrm{Fm})$. Ten grams of each inoculum were placed under each corm in order to guarantee the contact between the inoculum and the roots and therefore to favor the symbiosis between AMF and roots. Saffron corms used as controls were not inoculated (AMF-). Corms were not treated against fungal pathogens. A randomized block design was used with a total of 48 pots displayed in two experimental plot units (24 pots per unit) and three treatments (8 pots per treatment). Cultivation lasted for one cycle (August 2016-April 2017) in a heated glasshouse of the Department of Agricultural Forest and Food Sciences (DISAFA) of the University of Torino (Italy, $45^{\circ} 06^{\prime} 23.21^{\prime \prime} \mathrm{N}$ Lat, $7^{\circ} 57^{\prime} 82.83^{\prime \prime}$ E Long; $293 \mathrm{~m}$ a.s.l.), with an average temperature of $22^{\circ} \mathrm{C}$ during the day and $16^{\circ} \mathrm{C}$ in the night. Irrigation water $(\mathrm{pH} 7.4, \mathrm{EC} 505 \mu \mathrm{S} \mathrm{cm})$ was added weekly $(250 \mathrm{~mL}$ per pot) with a drip system. The corms were fertilized by fertigation (VIGORFLOR, AL.FE. srl, MN, Italy) every two weeks starting from the emergence of the spate, in quantities of $1.5 \mathrm{~g} \mathrm{~L}^{-1}$ of water. No flowering occurred because of the small size of the corms. 


\subsection{AMF Inoculation in Open Field}

Saffron corms with horizontal diameters of 2.5 to $3.5 \mathrm{~cm}$ were planted in the last ten days of August 2016 in two Alpine experimental sites located in the municipality of Morgex $\left(45^{\circ} 45^{\prime} 35.1^{\prime \prime} \mathrm{N}\right.$; $7^{\circ} 02^{\prime} 37.3^{\prime \prime} \mathrm{E} ; 1000 \mathrm{~m}$ a.s.l.) and Saint Cristophe $\left(45^{\circ} 45^{\prime} 06.9^{\prime \prime} \mathrm{N} ; 7^{\circ} 20^{\prime} 37.0^{\prime \prime} \mathrm{E} ; 700 \mathrm{~m}\right.$ a.s.l.) in Italy and cultivation lasted for two cycles (2016-2017 and 2017-2018). Both sites were cultivated with saffron for at least the previous three years. Before starting the experiment both fields were milled. To assess the effects of AMF inocula on saffron cultivation and production, the same treatments used in the pot trial were applied ( $\mathrm{Ri}, \mathrm{Ri}+\mathrm{Fm}$ or AMF-). A randomized block design was used, with three experimental plot units (blocks). Each plot unit consisted of 56 corms, planted in a $1.44 \mathrm{~m}^{2}$ area ( 39 corms $\mathrm{m}^{-2}$ ). Inter-row planting distance was of $7 \mathrm{~cm}$, while between-row distance was $25 \mathrm{~cm}$. Plots were separated from each other with at least $4 \mathrm{~m}$ distance. Before planting, $10 \mathrm{~g}$ of inoculum was placed under the corms to ensure contact between plant and the treatment. Irrigation was provided when needed and hand weeding control was conducted during cultivation, while no preplanting fertilization, tillage, or treatments against pathogens were applied. The two Alpine sites were characterized by semicontinental climate, with a long and cold winter (Supplementary Figure S1). In general, both sites had a sandy-loam texture according to the USDA classification and similar chemical characteristics (Supplementary Table S1).

\subsection{AMF Evaluation}

At the end of the vegetative phase in both pot (February 2017) and open field experiments (April 2017 and 2018), saffron roots were harvested, rid of topsoil, cleaned and stained with $0.1 \%$ $(w / v)$ cotton blue in $80 \%$ lactic acid overnight, then destained 3 times with lactic acid for $18 \mathrm{~h}$, cut into 1-cm-long segments and placed on microscope slides for further morphological analysis. Approximately 25 fragments were observed under light microscope for each replicate for a total of 300 root fragments. Fungal colonization was determined and calculated as described by Trouvelot et al. [48].

\subsection{Plant Performance and Saffron Yield in Open Field}

The daily number of picked flowers per corm (Supplementary Figure S2) and the yield of spice (i.e., stigmas dried at $40{ }^{\circ} \mathrm{C}$ for $8 \mathrm{~h}$ in an oven) were measured at flowering (November 2016 and 2017). When leaves were fully expanded (April 2017 and 2018), $50 \mathrm{mg}$ of fresh leaves per treatment were used to determine chlorophyll and carotenoids content as described by Caser et al. [49]. Simultaneous with leaf sampling, the Chlorophyll Meter SPAD-502 (Konica Minolta Sensing Inc., Osaka, Japan) was used to determine the relative quantity of chlorophyll present in 27 randomly selected plants per treatment in the field.

At the end of full plant development (April 2017 and 2018), the leaves length of all corms was measured. Then, 27 plants per treatment were lifted, and corms rid of topsoil, cleaned, and detunicated. The wilted rate as the ratio between the number of wilted corms and the total number of sown corms, the shoot caliber size, and the number, the size and the weight of replacement corms were determined.

\subsection{Saffron Extract Preparation and Quality}

The saffron aqueous extracts were prepared according to Gresta et al. [11]. Fifty mg of powdered saffron from each treatment and both cultivation years were put into $5 \mathrm{~mL}$ of deionized water. After stirring for $1 \mathrm{~h}$ at room temperature (circa $21^{\circ} \mathrm{C}$ ) in the dark, the solution was filtered with polytetrafluoroethylene (PTFE, VWR international, Milano, Italy) filters of $25 \mathrm{~mm}$ diameter and $0.45 \mu \mathrm{m}$ pore size. The saffron extract obtained was diluted 1:10 with deionized water $\left(1 \mathrm{mg} \mathrm{mL}^{-1}\right)$. Saffron extracts were analyzed with a spectrophotometer (Ultrospec 2100 Pro, GE Healthcare, UK Ltd., Little Chalfont, Buckinghamshire, UK) to determine the amount of picrocrocin, crocin, and safranal, according to ISO 3632 [7]. 


\subsection{Total Phenols}

The content of total phenols (TPC) was measured by using the Folin-Ciocalteu's phenolic method and determined as reported by Donno et al. [50]. Five hundred $\mu \mathrm{l}$ of saffron extract was added and mixed with $30 \mathrm{~mL}$ of deionized water, $2.5 \mathrm{~mL}$ of Folin-Ciocalteu's reagent (diluted 1:10), and, after eight minutes, $10 \mathrm{~mL}$ of $7.5 \%(w / v)$ saturated sodium carbonate solution. The solution was incubated at room temperature for $2 \mathrm{~h}$ in the dark and the absorbance was detected at $765 \mathrm{~nm}$ with a spectrophotometer (Ultrospec 2100 Pro, GE Healthcare, UK Ltd., Little Chalfont, Buckinghamshire,UK). The results were expressed as $\mathrm{mg}$ of gallic acid equivalents (GAE) per $100 \mathrm{~g}$ of fresh weight (FW).

\subsection{Total Anthocyanins}

The total anthocyanins content (TAC) was determined using the $\mathrm{pH}$-differential method [50]. Saffron extracts were added to a $\mathrm{pH} 1$ and $\mathrm{pH} 4.5$ buffer solutions. Absorbance of samples was determined at $515 \mathrm{~nm}$ and $700 \mathrm{~nm}$ after a 15 min equilibration. The formula for calculating TAC is as follows

$$
\mathrm{TAC}\left(\mathrm{mg} \mathrm{L}^{-1}\right)=(\mathrm{A} \times \text { sample dilution factor } \times 1000) /(\text { molar absorptivity } \times 1)
$$

where $\mathrm{A}$ is (Absorbance $515 \mathrm{~nm}$-Absorbance $700 \mathrm{~nm}$ ) at $\mathrm{pH}$ 1.0-(Absorbance $515 \mathrm{~nm}$ Absorbance $700 \mathrm{~nm}$ ) at $\mathrm{pH}$ 4.5. The results were expressed as milligrams of cyanidin 3-O-glucoside (C3G) per 100 gof fresh weight (mg of C3G $\left.100 \mathrm{~g}^{-1} \mathrm{FW}\right)$.

\subsection{Antioxidant Activity}

The antioxidant activity (AOA) was determined using the ferric reducing antioxidant power (FRAP) method as reported by Caser et al. [51] and the 2'-azinobis (3-ethylbenzothiazoline-6-sulfonic acid) (ABTS) method as described by Urbani et al. [52].

For the FRAP method, a total of $30 \mu \mathrm{L}$ of saffron extract was added and mixed with $90 \mu \mathrm{L}$ of deionized water and $900 \mu \mathrm{L}$ of the FRAP reagent. After incubation at $37^{\circ} \mathrm{C}$ for $30 \mathrm{~min}$, the absorbance of the solutions was measured at $595 \mathrm{~nm}$ using a spectrophotometer (Ultrospec 2100 Pro, GE Healthcare, UK Ltd., Little Chalfont, Buckinghamshire, UK). Results were expressed as millimoles of ferrous iron $\left(\mathrm{Fe}^{2+}\right)$ equivalents per kilogram of fresh weight.

The ABTS radical cation (ABTS +) was obtained by the reaction of 7.0 mM ABTS stock solution with $2.45 \mathrm{mM}$ potassium persulfate solution. After the incubation for 12-16 $\mathrm{h}$ before use in the dark and at room temperature, the solution was diluted with distilled water to obtain an absorbance of 0.70 $( \pm 0.02)$ at $734 \mathrm{~nm}$. After addition of $0.6 \mathrm{~mL}$ of diluted ABTS + solution to $180 \mu \mathrm{L}$ of saffron extract, the reaction was left in the dark at room temperature for six min. The absorbance was then measured at $734 \mathrm{~nm}$ using a spectrophotometer (Ultrospec 2100 Pro, GE Healthcare, UK Ltd., Little Chalfont, Buckinghamshire, UK). The antioxidant activity was expressed as $\mu \mathrm{mol}$ of Trolox equivalents per gram of dry weight ( $\left.\mu \mathrm{mol} \mathrm{TE} \mathrm{g}^{-1} \mathrm{DW}\right)$.

All analyses were performed in three replicates.

\subsection{Identification and Quantification of Bioactive Compounds}

The chromatographic analysis of saffron extracts (Supplementary Table S2) was conducted with an Agilent 1200 high-performance liquid chromatograph coupled to a diode array detector (HPLC-DAD; Agilent Technologies, Santa Clara, CA, USA), according to established methods [53]. Different chromatographic methods were used for analysis: benzoic acids (ellagic and gallic acids), catechins $((+)$ catechin and $(-)$ epicatechin), cinnamic acids (caffeic, chlorogenic, coumaric, and ferulic acids), flavonols (hyperoside, isoquercitrin, quercetin, quercitrin, and rutin), carotenoids (crocin I and II and safranal), and vitamin C (ascorbic + dehydroascorbic acids).

Four chromatographic methods were used to separate the bioactive molecules on a Kinetex C18 column $(4.6 \times 150 \mathrm{~mm}, 5 \mu \mathrm{m}$, Phenomenex, Torrance, CA, USA). Several mobile phases were used for 
bioactive compound identification and ultraviolet (UV) spectra were recorded at different wavelengths, based on HPLC methods, previously tested and validated [4], with some modifications. UV spectra were recorded at $330 \mathrm{~nm}(\alpha), 280 \mathrm{~nm}(\beta), 310$ and $441 \mathrm{~nm}(\chi)$, and 261 and $348 \mathrm{~nm}(\delta)$.

All single compounds were identified in samples by comparison and combination of their retention times and UV spectra with those of authentic standards analyzed with the same chromatographic conditions.

\subsection{Chemicals and Reagents}

All the chemicals and reagents used for the AMF evaluation, phenols, anthocyanins, FRAP, and ABTS assays and bioactive quantification were purchased from Sigma-Aldrich (Saint Louis, MO, USA).

\subsection{Statistical Analysis}

Arcsin transformation was performed on all percent incidence data before statistical analysis in order to improve homogeneity of variance (Levene test). All the analyzed data were checked for normality of variance. For all indices analyzed in the greenhouse assay, mean differences were computed using a one-way analysis of variance (ANOVA) with Tukey's post hoc test $(p \leq 0.05)$. Data from open field were analyzed by means of a linear mixed effect models considering AMF treatments as a fixed factor, year as a repeated measure, and sites and blocks as random factors. The following interactions (year $\times$ AMF treatment) were included in the model. Pairwise comparisons (according to sequential Bonferroni post hoc tests) were used to separate means when a treatment was significantly affecting the variable at a $p \leq 0.05$. All presented values are means of untransformed data. All computations were conducted with SPSS statistical package (version 25.0; SPSS Inc., Chicago, IL, USA).

\section{Results}

\subsection{Assessment of Saffron Mycorrhization at Pot and Open Field Scale}

Values concerning intensity of colonization in the root system and abundance of arbuscules or coils in the saffron roots in potted conditions are shown in Table 1. Corms treated with $\mathrm{Ri}+\mathrm{Fm}$ reached the highest level of mycorrhization (M\%) (93.33\%), however, high levels were also obtained with Ri inoculum $(71.37 \%)$. The Ri + Fm treatment also had the highest occurrence of arbuscules ( $\mathrm{a} \%)$ in the mycorrhizal portions (100\%), being significantly higher than Ri (82.99\%) and AMF-(0\%).

Table 1. AMF colonization indices (intensity in the whole root system, M; intensity of the mycorrhizal portions, m; presence of arbuscules in the whole root system, A; presence of arbuscules in the mycorrhizal portions, a) of Crocus sativus L. roots treated with the inoculum composed by Rhizophagus intraradices and Funneliformis mosseae $(\mathrm{Ri}+\mathrm{Fm})$, R. intraradices alone (Ri), or the control (AMF-) in the saffron pot cultivation.

\begin{tabular}{ccccc}
\hline & \multicolumn{4}{c}{ Index (\%) } \\
\hline Treatment & $\mathbf{M}$ & $\mathbf{m}$ & $\mathbf{A}$ & $\mathbf{a}$ \\
\hline $\mathrm{Ri}+\mathrm{Fm}$ & $93.33 \mathrm{a}$ & $93.33 \mathrm{a}$ & $93.33 \mathrm{a}$ & $100.00 \mathrm{a}$ \\
$\mathrm{Ri}$ & $71.37 \mathrm{~b}$ & $80.28 \mathrm{~b}$ & $58.98 \mathrm{~b}$ & $82.99 \mathrm{~b}$ \\
$\mathrm{AMF}-$ & $0.07 \mathrm{c}$ & $0.33 \mathrm{c}$ & $0.00 \mathrm{c}$ & $0.00 \mathrm{c}$ \\
\hline$p$ & $* * *$ & $* * *$ & $* * *$ & $* * *$
\end{tabular}

Mean values with the same letter are not statistically different at $p \leq 0.05$ according to Tukey's post-hoc tests. The statistical relevance is provided $(* * * p<0.001)$.

In open field conditions, the AMF root colonization measurements in C. sativus treated with Ri + Fm or with Ri alone during the two cultivation cycles are presented in Table 2. In general both the presence of arbuscules in the mycorrhizal portions $(\mathrm{a} \%)$ and in the whole root system $(\mathrm{A} \%)$ indices were affected by the inoculum composition only in the first cultivation year, while control plants 
(AMF-) were not colonized. In the second year, low root colonization was observed and no differences among the treated and untreated corms were detected.

Table 2. AMF colonization intensity in open field conditions after the first and second cultivation year of the whole root system (M) and of the mycorrhizal portions (m), and presence of arbuscules in the whole root system (A) and in the mycorrhizal portions (a) of Crocus sativus roots treated with inoculum composed of Rhizophagus intraradices and Funneliformis mosseae ( $\mathrm{Ri}+\mathrm{Fm})$, R. intraradices alone (Ri), or the control (AMF-).

\begin{tabular}{ccccc}
\hline Effect & \multicolumn{5}{c}{ Index (\%) } \\
\hline Year 1 & M & m & A & a \\
\hline $\mathrm{Ri}+\mathrm{Fm}$ & $11.6 \mathrm{a}$ & 11.7 & $4.0 \mathrm{a}$ & $26.6 \mathrm{a}$ \\
$\mathrm{Ri}$ & $13.8 \mathrm{a}$ & 14.2 & $6.9 \mathrm{a}$ & $38.1 \mathrm{a}$ \\
$\mathrm{AMF}-$ & $1.7 \mathrm{~b}$ & 3.4 & $0.0 \mathrm{~b}$ & $0.0 \mathrm{~b}$ \\
\hline$p$ & $*$ & $\mathrm{~ns}$ & $* * *$ & $* * *$ \\
\hline Year 2 & & & & \\
\hline $\mathrm{Ri}+$ Fm & 7.0 & 8.5 & 0.8 & 12.5 \\
$\mathrm{Ri}$ & 16.1 & 16.5 & 1.6 & 8.31 \\
$\mathrm{AMF}-$ & 4.73 & 6.1 & 2.5 & 18.8 \\
\hline$p$ & $\mathrm{~ns}$ & $\mathrm{~ns}$ & $\mathrm{~ns}$ & $\mathrm{~ns}$ \\
\hline Year $\times$ & $*$ & $\mathrm{n}$ & $*$ & $*$ \\
Treatment $(p)$ & & & & \\
\hline
\end{tabular}

Values with the same letter denote no significant differences. The statistical relevance is provided (ns, not significant; $\left.{ }^{*} p<0.05 ;{ }^{* * *} p<0.001\right)$.

\subsection{Impact of AMF Symbiosis on Saffron Productivity and Qualitative Traits in Open Field}

Significant differences between the two cultivation years emerged for several studied parameters. In general, the wilting rate, all the main productivity traits (number of flowers $\mathrm{m}^{-2}$, number of flowers per corm, $\mathrm{mg}$ of saffron $\mathrm{m}^{-2}$, saffron per flower, and the number of replacement corms), and the content of leaf chlorophyll and carotenoids significantly increased after the second year of cultivation (Table 3); a reduction in leaf length, SPAD unit, and shoot size was also observed.

Table 3. Effects of cultivation seasons (Year 1 and Year 2), AMF treatments (Ri + Fm was composed of Rhizophagus intraradices and Funneliformis mosseae, Ri of $R$. intraradices alone, and AMF-was the uninoculated control), and their interaction (Year $\times$ AMF treatment) on saffron plant growth and productivity based on linear mixed-effects models considering AMF treatments as a fixed factor, year as a repeated measure, and sites and blocks as random factors.

\begin{tabular}{|c|c|c|c|c|c|c|c|c|}
\hline \multirow[b]{2}{*}{ Traits } & \multicolumn{3}{|c|}{ Growing Seasons } & \multicolumn{4}{|c|}{ AMF Treatments } & \multirow{2}{*}{$\frac{\text { Year } \times \text { AMF }}{p}$} \\
\hline & Year 1 & Year 2 & $p$ & $\begin{array}{c}\mathrm{Ri}+ \\
\mathrm{Fm}\end{array}$ & $\mathbf{R i}$ & AMF- & $p$ & \\
\hline Wilting rate (\%) & 39.0 & 54.4 & $* * *$ & 44.3 & 50.0 & 45.8 & ns & ns \\
\hline Flower $\left(\mathrm{n} \mathrm{m}^{-2}\right)$ & 49.8 & 101.7 & $* * *$ & $91.8 \mathrm{a}$ & $61.9 \mathrm{~b}$ & $66.4 \mathrm{~b}$ & $*$ & $*$ \\
\hline Flower/corm (n) & 1.5 & 4.2 & $* * *$ & $5.1 \mathrm{a}$ & $3.8 \mathrm{~b}$ & $3.9 \mathrm{~b}$ & * & * \\
\hline Saffron yield $\left(\mathrm{mg} \mathrm{m}^{-2}\right)$ & 278.0 & 700.0 & $* * *$ & $645.3 \mathrm{a}$ & $377.4 \mathrm{~b}$ & $477.2 \mathrm{~b}$ & * & * \\
\hline Saffron/flower (mg) & 6.0 & 7.0 & $* *$ & $7.1 \mathrm{a}$ & $5.8 \mathrm{~b}$ & $7.3 \mathrm{a}$ & * & * \\
\hline Leaf length $(\mathrm{cm})$ & 36.8 & 24.1 & $* * *$ & 31.4 & 30.3 & 29.9 & ns & ns \\
\hline SPAD unit & 74.8 & 45.7 & $* * *$ & 60.0 & 61.1 & 59.7 & ns & ns \\
\hline Shoot size (mm) & 5.3 & 4.1 & $* *$ & $5.5 \mathrm{a}$ & $3.3 \mathrm{~b}$ & $4.2 \mathrm{ab}$ & $* *$ & $*$ \\
\hline Corm size (mm) & 21.1 & 20.2 & ns & 19.8 & 20.0 & 22.2 & ns & ns \\
\hline Replacement corm (n) & 2.2 & 3.7 & $*$ & 2.8 & 3.4 & 2.7 & ns & ns \\
\hline Corm weight $(\mathrm{g})$ & 7.7 & 6.5 & ns & 7.8 & 7.4 & 6.3 & ns & ns \\
\hline Chlorophyll ( $\left.\mu \mathrm{g} \mathrm{mg}^{-1}\right)$ & 1.6 & 4.1 & $* * *$ & 2.9 & 2.9 & 2.7 & ns & ns \\
\hline Carotenoids $\left(\mu \mathrm{g} \mathrm{mg}^{-1}\right)$ & 0.6 & 2.2 & $* * *$ & 1.4 & 1.5 & 1.4 & ns & ns \\
\hline
\end{tabular}

Values with the same letter denote no significant differences. The statistical relevance is provided (ns, not significant; ${ }^{*} p<0.05$; ${ }^{* *} p<0.01$; ${ }^{* * *} p<0.001$ ). 
In Table 3, the productivity and growth traits influenced by the AMF treatments are also reported. Particularly, the inoculum composed of the mix of $R$. intraradices and $F$. mosseae significantly increased the number of flowers $\mathrm{m}^{-2}(+138.2 \%)$, the number of flowers corm ${ }^{-1}(+130.8 \%)$, and the $\mathrm{mg}$ of saffron $\mathrm{m}^{-2}(+135.2 \%)$ in comparison to other treatments. In contrast, the $\mathrm{mg}$ of saffron flower ${ }^{-1}$ and the shoot size were significantly reduced ( $-20 \%$ and $-40 \%$, respectively) by the inoculum of $R$. intraradices alone in comparison to Ri + Fm and AMF-. Significant interaction between cultivation year and AMF treatments resulted for the number of flowers $\mathrm{m}^{-2}$, the number of flowers $\mathrm{corm}^{-1}$, saffron yield, saffron flower ${ }^{-1}$, and shoot size.

Regarding the synthesis of bioactive molecules in the studied saffron spice, differences between the two cultivation seasons occurred (Table 4). Overall, the saffron produced at the two experimental sites belonged to the quality category I for the picrocrocin, safranal, and crocins analysis [7] with a significant increase after the second cultivation year. On the contrary, different bioactive compounds (isoquercitirin, quercitrin, ellagic acid, safranal, and total vitamin C) were significantly reduced. Very few differences were observed among AMF treatments (Table 4). Both Ri + Fm and Ri positively affected the antioxidant activity (FRAP assay) of the saffron produced. While, the effect of the Ri inoculum significantly increased the absorbance value of picrocrocin (ISO 3632) and the content of quercitrin in comparison to $\mathrm{Ri}+\mathrm{Fm}$, and the content of crocin II compared to AMF- (Table 4). A significant interaction between cultivation seasons and AMF treatments resulted for picrocrocin (ISO), quercitrin, crocin II, and antioxidant activity (FRAP assay).

Table 4. Effects of cultivation seasons (Year 1 and Year 2), AMF treatments (Ri + Fm was composed of Rhizophagus intraradices and Funneliformis mosseae, Ri of R. intraradices alone, and AMF- was the uninoculated control), and their interaction (year $\times$ AMF treatment) on bioactive compounds, total polyphenol content (TPC), anthocyanins, quality traits as defined by ISO 3632 [7], and antioxidant activity of the produced saffron based on liner mixed-effects models considering AMF treatments as a fixed factor, year as a repeated measure, and sites and blocks as random factors.

\begin{tabular}{|c|c|c|c|c|c|c|c|c|}
\hline \multirow[b]{2}{*}{ Traits } & \multicolumn{3}{|c|}{ Growing Seasons } & \multicolumn{4}{|c|}{ AMF Treatments } & \multirow{2}{*}{$\begin{array}{c}\text { Year } \times \mathrm{AMF} \\
p\end{array}$} \\
\hline & Year 1 & Year 2 & $p$ & $\begin{array}{l}\mathrm{Ri}+ \\
\mathrm{Fm}\end{array}$ & $\mathbf{R i}$ & AMF- & $p$ & \\
\hline \multicolumn{9}{|l|}{ ISO 3632 [7] } \\
\hline Picrocrocin & 131.4 & 135.0 & $*$ & $130.2 \mathrm{~b}$ & $138.7 \mathrm{a}$ & $136.1 \mathrm{a}$ & * & $*$ \\
\hline Safranal & 38.8 & 44.2 & $* *$ & 39.9 & 43.8 & 40.8 & ns & ns \\
\hline Crocins & 207.1 & 368.5 & $* * *$ & 275.9 & 303.5 & 284.1 & ns & ns \\
\hline \multicolumn{9}{|l|}{$\begin{array}{c}\text { Bioactive compounds (mg } 100 \mathrm{~g}^{-1} \\
\text { dry weight) }\end{array}$} \\
\hline Coumaric acid & 23.6 & 23.5 & ns & 23.6 & 23.5 & 23.7 & ns & ns \\
\hline Isoquercitrin & 2.6 & 2.5 & $*$ & 2.5 & 2.5 & 2.6 & ns & ns \\
\hline Quercitrin & 22.8 & 16.0 & $* * *$ & $17.0 \mathrm{~b}$ & $22.3 \mathrm{a}$ & $18.9 \mathrm{ab}$ & $*$ & $*$ \\
\hline Gallic acid & 5.0 & 4.9 & ns & 4.9 & 4.9 & 5.1 & ns & ns \\
\hline Ellagic acid & 2.7 & 0.8 & $* * *$ & 2.0 & 2.1 & 1.3 & ns & ns \\
\hline Catechin & 3.4 & 3.1 & ns & 2.7 & 3.0 & 4.3 & ns & ns \\
\hline Epicatechin & 6.1 & 8.3 & ns & 6.4 & 6.3 & 9.0 & ns & ns \\
\hline Safranal & 4.4 & 4.0 & $* * *$ & 4.2 & 4.3 & 4.2 & ns & ns \\
\hline Crocin I & 32.5 & 67.9 & $* *$ & 49.2 & 37.7 & 63.8 & ns & ns \\
\hline Crocin II & 31.1 & 36.6 & * & $35.0 \mathrm{ab}$ & $38.8 \mathrm{a}$ & $27.7 \mathrm{~b}$ & $*$ & $*$ \\
\hline Total Vitamin C & 76.5 & 67.0 & $* *$ & 71.4 & 70.1 & 73.2 & ns & ns \\
\hline TPC $\left(m_{\text {GAE }} 100 \mathrm{~g}^{-1} \mathrm{DW}\right)$ & 1340.7 & 2355.5 & ns & 1906.1 & 1868.8 & 1819.5 & ns & ns \\
\hline Antocyanins (mg 3 G $\left.100 \mathrm{~g}^{-1} \mathrm{DW}\right)$ & 1866.5 & 1633.6 & ns & 964.1 & 2418.8 & 1867.3 & ns & ns \\
\hline \multicolumn{9}{|l|}{ Antioxidant activity } \\
\hline FRAP $\left(\mathrm{mmol} \mathrm{Fe}^{2+} \mathrm{kg}^{-1}\right)$ & 408.9 & 1937.1 & $* * *$ & $424.8 \mathrm{a}$ & $463.8 \mathrm{a}$ & $338.2 \mathrm{~b}$ & $* * *$ & $* * *$ \\
\hline $\operatorname{ABTS}\left(\mu \mathrm{mol}_{\mathrm{TE}} \mathrm{g}^{-1}\right)$ & 4.2 & 4.6 & ns & 4.3 & 4.5 & 4.6 & ns & ns \\
\hline
\end{tabular}

Values with the same letter denote no significant differences. The statistical relevance is provided (ns, not significant; $\left.{ }^{*} p<0.05 ;{ }^{* *} p<0.01 ;{ }^{* * *} p<0.001\right)$. 


\section{Discussion}

\subsection{AMF Colonization}

In the literature only some studies report AMF colonization of C. sativus roots. In the present study, their presence in potted cultivation was detected in C. sativus roots subjected to both AMF treatments $(\mathrm{Ri}+\mathrm{Fm}$ and $\mathrm{Ri}$ ). Saffron root fragments showed extensive AM fungal colonization, characterized by a moderate to high intensity of colonization and arbuscule formation. Saffron root colonization in the present pot cultivation trial was markedly superior to the results obtained in the open field test. This could be due to the antagonistic action of the naturally occurring fungi in the soil that compete with the AMF and by the different cultivation substrate used. However, to the best of our knowledge, this is the first report clearly indicating and measuring successful symbiosis between $C$. sativus roots and AMF under pot cultivation conditions.

Our open field data are equal or lower than findings obtained in other open field trials as reported by Aimo et al. [40] and Lone et al. [43]. Applying the percent colonization method for root AMF evaluation, these authors reached a maximum of $30 \%$ and $60 \%$ mycorrhizal colonization in saffron roots in Italy and Kashmir cultivation fields when using a mix of AMF belonging to the genus Glomus, respectively. In a similar study conducted in Iranian fields, the percentage of root colonization of saffron was of 39\% [42], while in a field in Kashmir, ranged between 15 and 90\% on the basis of the season [43]. As reported in Supplementary Table S1, P Olsen values measured at the experimental sites are high $\left(>69.2 \mathrm{mg} \mathrm{kg}^{-1}\right)$, indicating the potential for a detrimental effect of $\mathrm{P}$ on AMF colonization in our experiment. As the cost of the symbiosis to the plant outweighs the benefit of access to $P$ via the fungal pathway, plants reduce fungal access to carbohydrate [54]. Similar data were reported also in other species such as Zea mays L. in which the AMF root colonization was reduced with a soil P content of $90 \mathrm{mg} \mathrm{kg}^{-1}$ [55]. In other geophyte plants, such as Allium tricoccum Aiton., a low level of AMF symbiosis was observed in the absence of leaves and photosynthetic activity. However, once leaves elongate in early spring, root colonization increases rapidly. This is similar to the pattern of Maianthemum racemosum L., where AMF colonization peaked during vegetative growth [56]. Here, AMF sampling was performed during maximum leaf elongation, and therefore, the detection of low colonization is likely more related to soil characteristics than to other physiological or biochemical parameters.

Taken together, all these findings indicated that under open field conditions in alpine environments, AMF colonization was substantially lower than under pot conditions as already indicated in literature. This is in agreement with the meta-analysis of Berruti et al. [27], in which successful outcomes of AMF inoculation were more often found in controlled (greenhouse and growth chamber) conditions. In this condition, environmental extremes and variation are minimized or absent [38]. Moreover, one of the most important confounding factors in pot or field experiments is the effect of root temperature on the AMF growth [57]. The higher temperatures typical of greenhouse conditions favor greater growth and superior colonization by AMF [58].

\subsection{AMF Modulate Crop Performance and Spice Quality}

Flower yield is a difficult parameter to forecast in saffron since it is influenced by a combination of agronomic, biological, and environmental factors [11]. Generally, a saffron field may produce from 200 to $3000 \mathrm{mg} \mathrm{m}^{-2}$ of spice, depending on the cultivation factors [11] and obviously, by the planting density, which may vary considerably. By planting at a 55 corms $\mathrm{m}^{-2}$ density in southern Italy (Sicily), Gresta et al. [3] obtained more than $1200 \mathrm{mg} \mathrm{m}^{-2}$. In the area of Navelli (central Italy) [59], with a similar corm density, the average yield ranged between 1000 and $1600 \mathrm{mg} \mathrm{m}^{-2}$. In Iranian fields with a density of 150 and 100 corms $\mathrm{m}^{-2}$, Mollafilabi et al. [60] and Koocheki et al. [61] obtained 740 and $370 \mathrm{mg} \mathrm{m}^{-2}$ of saffron, respectively. Recently, the path coefficient analysis conducted by Bayat et al. [62] highlighted that fresh stigma weight, flower number, dry stigma and flower weight, 
leaf size, and number and size of replacement corms have the highest positive correlation with saffron yield.

Arbuscular mycorrhizal fungi are known to be beneficial to several important plants, including some medicinal plants [30]. Unfortunately, very scarce reports of the effective role of AMF in saffron yield are available. Only, Aimo et al. [40] indicate an increase in flower production $\mathrm{m}^{-2}$ (equal to $68 \%$, compared to control) using a mix of AMF species belonging to the genus Glomus. Our results are generally more supportive of the benefits of AMF inoculation with an increase of flower production $\mathrm{m}^{-2}$ of circa $140 \%$. Taken together, these findings suggest a beneficial effect of AMF inoculation with a mixture of $R$. intraradices and $F$. mosseae on saffron yield performance.

Few spices are able to provide the combination of color, taste, and aroma to the foods and possess several nutraceutical properties for human health as saffron. Most of the beneficial effects of saffron, recognized since ancient times, are due mainly to its total phenolic content (TPC) and antioxidant activity (FRAP and ABTS assays). $R$. intraradices alone was found to induce an increase in secondary metabolite contents, such as terpenes and phenolics, in Salvia officinalis L. [63] and Echinacea purpurea L. [64]. Overall, the saffron produced in the studied alpine areas had very high TPC (ranges between 1340.7 and $2355.5 \mathrm{mg} \mathrm{GAE} 100 \mathrm{~g}^{-1} \mathrm{DW}$ ), which was more than saffron cultivated in different areas of Lebanon (160 mgGAE $100 \mathrm{~g}^{-1} \mathrm{DW}$ ) [65], and is much greater when compared with other common food additives and spices, such as Eugenia caryophylate (Thunb.), Lavandula spp., Curcuma domestica Val, and Curcuma longa L. (0.26, 0.22, 23, and 36 mg GAE $100 \mathrm{~g} \mathrm{~g}^{-1}$ DW, respectively) (Table 4) [66,67]. Results of ABTS and FRAP assays also demonstrated elevated antioxidant activity (Table 4). ABTS assay values were comparable to what was found in Greek saffron by Ordoudi et al. [68]. FRAP assay values (between 408.9 and $1937.1 \mathrm{mmol} \mathrm{Fe}{ }^{2+} \mathrm{kg}^{-1}$ ) were generally higher in comparison to the Iranian samples (circa $570 \mathrm{mmol} \mathrm{Fe} \mathrm{eg}^{2+} \mathrm{kg}^{-1}$ ) analyzed by Karimi et al. [69]. The saffron produced in the west Italian Alps also had different bioactive compounds (Table 4) known for their health-promoting activity, that is, cinnamic acids, flavonols, benzoic acids, catechins, and carotenoids [50]. Other studies report that water-soluble carotenoids such as crocins have antioxidant effects superior to $\alpha$-tocopherol [67]. It was recently observed in a clinical study that high crocin I and crocin II contents (4000 and $1000 \mathrm{mg}$, respectively) inhibit $\beta$-amyloid and tau aggregation [70]. Apart from crocins, Asdaq and Inamdar [71] suggest that flavonols are responsible for the synergistic antihyperlipidemic and antioxidant potential of saffron. Amin et al. [72] indicated that a concentration of $1 \mathrm{mg}$ of safranal attenuated the behavioral symptoms of neuropathic pain. Our data indicate that the saffron produced presented high crocin II content (27.7-38.8 mg $\left.100 \mathrm{~g}^{-1} \mathrm{DW}\right)$, almost in line with the saffron produced in Sardinia (Italy, DOP Zafferano di Sardegna) [73], while also presenting a higher content of gallic acid compared to what was found in Iranian and Greek saffron (2 mg and $1.2100 \mathrm{~g}^{-1} \mathrm{DW}$ ) by Karimi et al. [69] and Proestos et al. [74], respectively. Thus, the saffron obtained could be of particular interest for its elevated antioxidant properties.

\section{Conclusions}

Saffron quality may vary greatly by site on the basis of several factors, among which are climatic conditions and cultivation techniques. We hereby provide data indicating the production of high quality saffron in marginal alpine areas, thus confirming that this crop is a strategic resource and good alternative for mountainous areas building multifunctional economies. Besides the phytochemical profile highlighted, the crop had many bioactive compounds. The use of arbuscular mycorrhizal symbionts as biostimulants positively affected saffron cultivation, mainly by increasing crop productivity, and partially by increasing the content of important nutraceutical compounds. Specifically, the inoculum composed by R. intraradices and F. mosseae was particularly effective in increasing flower production and saffron yield, while $R$. intraradices alone increased the content of some bioactive compounds-picrocrocin, quercitrin, crocin II—as well as antioxidant activity. Since saffron is the world's highest priced spice, the increases in yield and quality obtained using AMF should allow for an increase in profitability. 
Furthermore, a new perspective can be envisaged. Since AMF symbiosis was more effective under soilless pot cultivation, this system may be a valuable alternative for saffron production and further work is underway to assess the potential of AMF inocula in saffron soilless cultivation.

Supplementary Materials: The following are available online at http:/ / www.mdpi.com/2073-4395/9/1/12/s1, Figure S1: Climatic conditions of the Alpine experimental sites, Figure S2: Effects of AMF inoculum composed by Rhizophagus intraradices and Funneliformis mosseae $(\mathrm{Ri}+\mathrm{Fm}), \mathrm{R}$. intraradices alone (Ri), or control (AMF-) on flower production m-2 during the first (a) and second (b) cultivation cycle, Table S1: Physical and chemical properties of the soils collected in the three saffron experimental fields located in the municipality of Saint Cristophe and Morgex (north west Italy), Table S2: Characteristics of the HPLC methods applied to analyse the bioactive compounds present in the studied saffron samples.

Author Contributions: M.C., A.B., E.L., V.B., and V.S. contributed to the experimental design. M.C., Í.M.M.V., S.D., D.D., A.B., and V.S. acquired and interpreted data. M.C. drafted the manuscript. V.B. and V.S. conceived, coordinated the work, and critically revised the manuscript.

Funding: This research was funded by the project titled 'SaffronALP — Lo zafferano di montagna: tecniche sostenibili per una produzione di qualità'-Fondazione Cassa di Risparmio di Torino $(\mathrm{RF}=2017.1966)$ and by the program Interreg V-A Francia Italia Alcotra "Attività innovative per lo sviluppo della filiera transfrontaliera del fiore edule-Antea' n. 1139.

Acknowledgments: The authors acknowledge Dario Sacco for statistical assistance, Alessandro Putzolu for technical assistance, and Azienda Agricola La Branche di Diego Bovard and Azienda Agricola Rosset for providing plant material and hosting cultivation.

Conflicts of Interest: The authors declare no conflict of interest.

\section{References}

1. Molina, R.; García-Luis, A.; Coll, V.; Ferrer, C.; Valero, M.; Navarro, Y.; Guardiola, J. Flower formation in the saffron crocus (Crocus sativus L.). The role of temperature. Acta Hortic. 2004, 650, 39-47. [CrossRef]

2. Mollafilabi, A. Production and Modern Agronomic of Saffron; Scientific and Industrial Research Organization of Khorasan: Mashhad, Iran, 2004; pp. 22-35.

3. Gresta, F.; Santonoceto, C.; Avola, G. Crop rotation as an effective strategy for saffron (Crocus sativus L.) cultivation. Sci. Hortic. 2016, 211, 34-39. [CrossRef]

4. D'Archivio, A.; Giannitto, A.; Maggi, M.; Ruggieri, F. Geographical classification of Italian saffron (Crocus sativus L.) based on chemical constituents determined by high-performance liquid-chromatography and by using linear discriminant analysis. Food Chem. 2016, 212, 110-116. [CrossRef] [PubMed]

5. Carmona, M.; Zalacain, A.; Pardo, J.; López, E.; Alvarruiz, A.; Alonso, G. Influence of different drying and aging conditions on saffron constituents. J. Agric. Food Chem. 2005, 18, 3974-3979. [CrossRef] [PubMed]

6. Tong, Y.; Yan, Y.; Zhu, X.; Liu, R.; Gong, F.; Zhang, L.; Wang, P. Simultaneous quantification of crocetin esters and picrocrocin changes in Chinese saffron by high-performance liquid chromatography-diode array detector during 15 years of storage. Pharmacogn. Mag. 2015, 11, 540-545. [PubMed]

7. ISO 3632-1:2011. Spices-Saffron (Crocus sativus L.). Food Products SC 7, Spices, Culinary Herbs and Condiments; International Organization for Standardization: Geneva, Switzerland, 2011.

8. Shahi, T.; Assadpour, E.; Jafari, S. Main chemical compounds and pharmacological activities of stigmas and tepals of 'red gold'; saffron. Trends Food Sci. Technol. 2016, 58, 69-78. [CrossRef]

9. Bagur, M.; Salinas, G.; Jiménez-Monreal, A.; Chaouqi, S.; Llorens, S.; Martinez-Tomé, M.; Alonso, G. Saffron: An Old Medicinal Plant and a Potential Novel Functional Food. Molecules 2018, 23, 30. [CrossRef]

10. De Juan, J.A.; Córcoles, H.L.; Muñoz, R.M.; Picornell, M.R. Yield and yield components of saffron under different cropping systems. Ind. Crops Prod. 2009, 30, 212-219. [CrossRef]

11. Gresta, F.; Lombardo, G.; Siracusa, L.; Ruberto, G. Saffron an alternative crop for sustainable agricultural systems. A review. Agron. Sustain. Dev. 2008, 28, 95-112. [CrossRef]

12. Yarami, N.; Kamgar-Haghighi, A.A.; Sepaskhah, A.R.; Zand-Parsa, S. Determination of the potential evapotranspiration and crop coefficient for saffron using a water-balance lysimeter. Arch. Agron. Soil Sci. 2011, 57, 727-740. [CrossRef]

13. Maggio, A.; Raimondi, G.; Martino, A.; De Pascale, S. Soilless cultivation of saffron in mediterranean environment. Acta Hortic. 2006, 718, 515-522. [CrossRef] 
14. Molina, R.; Valero, M.; Navarro, Y.; Guardiola, J.; García-Luis, A. Temperature effects on flower formation in saffron (Crocus sativus L.). Sci. Hortic. 2005, 103, 361-379. [CrossRef]

15. Giorgi, A.; Pentimalli, D.; Giupponi, L.; Panseri, S. Quality traits of saffron (Crocus sativus L.) produced in the Italian Alps. Open Agric. 2017, 2, 52-57. [CrossRef]

16. Manzo, A.; Panseri, S.; Bertoni, D.; Giorgi, A. Economic and qualitative traits of Italian Alps saffron. J. Mt. Sci. 2015, 12, 1542-1550. [CrossRef]

17. De Pascale, S.; Rouphael, Y.; Colla, G. Plant biostimulants: Innovative tool for enhancing plant nutrition in organic farming. Eur. J. Hortic. Sci. 2017, 82, 277-285. [CrossRef]

18. De Ponti, T.; Rijk, B.; Van Ittersum, M. The crop yield gap between organic and conventional agriculture. Agric. Syst. 2012, 108, 1-9. [CrossRef]

19. Colla, G.; Nardi, S.; Cardarelli, M.; Ertani, A.; Lucini, L.; Canaguier, R.; Rouphael, Y. Protein hydrolysates as biostimulants in horticulture. Sci. Hortic. 2015, 196, 28-38. [CrossRef]

20. Rouphael, Y.; Cardarelli, M.; Colla, G. Role of arbuscular mycorrhizal fungi in alleviating the adverse effects of acidity and aluminium toxicity in zucchini squash. Sci. Hortic. 2015, 188, 97-105. [CrossRef]

21. Mercy, L.; Lucic-Mercy, E.; Nogales, A.; Poghosyan, A.; Schneider, C.; Arnholdt-Schmitt, B. A Functional Approach towards Understanding the Role of the Mitochondrial Respiratory Chain in an Endomycorrhizal Symbiosis. Front. Plant Sci. 2017, 8, 417. [CrossRef]

22. Błaszkowski, J.; Kovács, G.; Balázs, T.; Orłowska, E.; Sadravi, M.; Wubet, T.; Buscot, F. Glomus africanum and G. iranicum, two new species of arbuscular mycorrhizal fungi (Glomeromycota). Mycologia 2010, 102, 1450-1462. [CrossRef]

23. Johnson, N.; Gehring, C. Mycorrhizas: Symbiotic mediators of rhizosphere and ecosystem processes. Rhizosphere 2007, 73-100. [CrossRef]

24. Berruti, A.; Borriello, R.; Lumini, E.; Scariot, V.; Bianciotto, V.; Balestrini, R. Application of laser microdissection to identify the mycorrhizal fungi that establish arbuscules inside root cells. Front. Plant Sci. 2013, 4, 135. [CrossRef] [PubMed]

25. Borriello, R.; Berruti, A.; Lumini, E.; Della Beffa, M.T.; Scariot, V.; Bianciotto, V. Edaphic factors trigger diverse AM fungal communities associated to exotic camellias in closely located Lake Maggiore (Italy) sites. Mycorrhiza 2015, 25, 253-265. [CrossRef] [PubMed]

26. Liu, J.; Wu, L.; Wei, S.; Xiao, X.; Su, C.; Jiang, P.; Song, Z.; Wang, T.; Yu, Z. Effects of arbuscular mycorrhizal fungi on the growth, nutrient uptake and glycyrrhizin production of licorice (Glycyrrhiza uralensis Fisch). Plant Growth Regul. 2007, 52, 29-39. [CrossRef]

27. Berruti, A.; Lumini, E.; Balestrini, R.; Bianciotto, V. Arbuscular mycorrhizal fungi as natural biofertilizers: Let's benefit from past successes. Front. Microbiol. 2016, 6, 1559. [CrossRef] [PubMed]

28. Bianciotto, V.; Victorino, I.; Scariot, V.; Berruti, A. Arbuscular mycorrhizal fungi as natural biofertilizers: Current role and potential for the horticulture industry. Acta Hortic. 2018, 1191, 207-215. [CrossRef]

29. López-Ráez, J.; Verhage, A.; Fenández, I.; García, J.; Azcón-Aguilar, C.; Flors, V.; Pozo, M. Hormonal and transcriptional profiles highlight common and differential host responses to arbuscular mycorrhizal fungi and the regulation of the oxylipin pathway. J. Exp. Bot. 2010, 61, 2589-2601. [CrossRef]

30. De Sousa Oliveira, M.; da Silva Campos, M.; de Albuquerque, U.P.; da Silva, F.S.B. Arbuscular mycorrhizal fungi (AMF) affects biomolecules content in Myracrodruon urundeuva seedlings. Ind. Crops Prod. 2013, 50, 244-247. [CrossRef]

31. Bona, E.; Lingua, G.; Manassero, P.; Cantamessa, S.; Marsano, F.; Todeschini, V.; Copetta, A.; D'Agostino, G.; Massa, N.; Avidano, L.; et al. AM fungi and PGP pseudomonads increase flowering, fruit production, and vitamin content in strawberry grown at low nitrogen and phosphorus levels. Mycorrhiza 2015, 25, 181-193. [CrossRef]

32. Lazzara, S.; Militello, M.; Carrubba, A.; Napoli, E.; Saia, S. Arbuscualr mycorrhizal fungi altered the hypericin, pseudohypericin, and hyperforin conten in flowers of Hypericum perforatum grown under contrasting $\mathrm{P}$ availability in a highly organic substrate. Mycorrhiza 2017, 27, 345-354. [CrossRef]

33. Jurkiewicz, A.; Ryszka, P.; Anielska, T.; Waligórski, P.; Bialońska, D.; Góralska, K.; Tsimilli-Michael, M.; Turnau, K. Optimization of culture conditions of Arnica montana L.: Effects of mycorrhizal fungi and competing plants. Mycorrhiza 2010, 20, 293-306. [CrossRef] [PubMed] 
34. Zeng, Y.; Guo, L.; Chen, B.; Hao, Z.; Wang, J.; Huang, L.; Yang, G.; Cui, X.; Yang, L.; Wu, Z.; et al. Arbuscular mycorrhizal symbiosis and active ingredients of medicinal plants: Current research status and prospectives. Mycorrhiza 2013, 23, 253-265. [CrossRef] [PubMed]

35. Giovannetti, M.; Avio, L.; Sbrana, C. Improvement of nutraceutical value of food by plant symbionts. In Natural Products, Phytochemistry, Botany and Metabolism of Alkaloids, Phenolics and Terpenes; Ramawat, K.G., Merillon, J.M., Eds.; Springer: Berlin, Germany, 2013; pp. 2641-2662.

36. Rydlová, J.; Jelínkova, M.; Dušek, K.; Dušková, E.; Vosátka, M.; Püschel, D. Arbuscular mycorrhiza differentially affects synthesis of essential oils in coriander and dill. Mycorrhiza 2016, 26, 123-131. [CrossRef] [PubMed]

37. Hart, M.M.; Antunes, P.M.; Chaudhary, V.B.; Abbott, L.K. Fungal inoculants in the field: Is the reward greater than the risk? Funct. Ecol. 2017, 32, 126-135. [CrossRef]

38. Ryan, M.H.; Graham, J.H. Little evidence that farmers should consider abundance or diversity of arbuscular mycorrhizal fungi when managing crops. New Phytol. 2018, 220, 1092-1107. [CrossRef] [PubMed]

39. Berg, G. Plant-microbe interactions promoting plant growth and health: Perspectives for controlled use of microorganisms in agriculture. Appl. Microbiol. Biotechnol. 2009, 84, 11-18. [CrossRef] [PubMed]

40. Aimo, S.; Gosetti, F.; D’Agostino, G.; Gamalero, E.; Gianotti, V.; Bottaro, M.; Gennaro, M.; Berta, G. Use of arbuscular mycorrhizal fungi and beneficial soil bacteria to improve yield and quality of saffron (Crocus sativus L.). Acta Hortic. 2010, 850, 159-162. [CrossRef]

41. Venkateshwaran, M.; Volkening, J.; Sussman, M.; Ané, J. Symbiosis and the social network of higher plants. Curr. Opin. Plant Biol. 2013, 16, 118-127. [CrossRef]

42. Mohebi-Anabat, M.; Riahi, H.; Zanganeh, S.; Sadeghnezhad, E. Effects of arbuscular mycorrhizal inoculation on the growth, photosynthetic pigments and soluble sugar of Crocus sativus L. (saffron) in autoclaved soil. Int. J. Agron. Agric. Res. 2015, 6, 296-304.

43. Lone, R.; Shuab, R.; Koul, K. AMF association and their effect on metabolite mobilization, mineral nutrition and nitrogen assimilating enzymes in saffron (Crocus sativus) plant. J. Plant Nutr. 2016, 39, 1852-1862. [CrossRef]

44. Shajari, M.A.; Moghaddam, P.R.; Ghorbani, R.; Koocheki, A. Increasing saffron (Crocus sativus L.) corm size through the mycorrhizal inoculation, humic acid application and irrigation managements. J. Plant Nutr. 2018, 41, 1047-1064. [CrossRef]

45. Moghaddam, P.R.; Koocheki, A.; Molafilabi, A.; Seyyedi, M. Effect of biological and chemical fertilizers on replacement corm and flower yield of saffron (Crocus sativus L.). Iran. J. Crop Sci. 2013, 15, 234-246.

46. Cusano, E.; Consonni, R.; Petrakis, E.A.; Astraka, K.; Cagliani, L.R.; Polissiou, M.G. Integrated analytical methodology to investigate bioactive compounds in Crocus sativus L. flowers. Phytochem. Anal. 2018, 29, 476-486. [CrossRef]

47. Vahedi, M.; Kabiri, M.; Salami, S.A.; Rezadoost, H.; Mirzaie, M.; Kanani, M.R. Quantitative HPLC-based metabolomics of some Iranian saffron (Crocus sativus L.) accessions. Ind. Crops Prod. 2018, 118, 26-29. [CrossRef]

48. Trouvelot, A.; Kough, J.; Gianinazzi-Pearson, V. Mesure du taux de mycorhization VA d'un système radiculaire. Recherche de méthodes d'estimation ayant une signification fonctionnelle. In Mycorrhizae: Physiology and Genetics; Gianinazzi-Pearson, V., Gianinazzi, S., Eds.; INRA Press: Paris, France, 1986; pp. 217-221.

49. Caser, M.; D’Angiolillo, F.; Chitarra, W.; Lovisolo, C.; Ruffoni, B.; Pistelli, L.; Pistelli, L.; Scariot, V. Ecophysiological and phytochemical responses of Salvia sinaloensis Fern. to drought stress. Plant Growth Regul. 2018, 84, 383-394. [CrossRef]

50. Donno, D.; Beccaro, G.; Mellano, M.; Cerutti, A.; Bounous, G. Goji berry fruit (Lycium spp.): Antioxidant compound fingerprint and bioactivity evaluation. J. Funct. Foods 2015, 18, 1070-1085. [CrossRef]

51. Caser, M.; D’Angiolillo, F.; Chitarra, W.; Lovisolo, C.; Ruffoni, B.; Pistelli, L.; Pistelli, L.; Scariot, V. Water deficit regimes trigger changes in valuable physiological and phytochemical parameters in Helichrysum petiolare Hilliard \& B.L. Burtt. Ind. Crops Prod. 2016, 83, 680-669.

52. Urbani, E.; Blasi, F.; Simonetti, M.; Chiesi, C.; Cossignani, L. Investigation on secondary metabolite content and antioxidant activity of commercial saffron powder. Eur. Food Res. Technol. 2016, 242, 987-993. [CrossRef] 
53. Donno, D.; Mellano, M.G.; Prgomet, Z.; Beccaro, G.L. Advances in Ribes x nidigrolaria Rud. Bauer \& A. Bauer fruits as potential source of natural molecules: A preliminary study on physico-chemical traits of an underutilized berry. Sci. Hortic. 2018, 237, 20-27.

54. Gosling, P.; Mead, A.; Proctor, M.; Hammond, J.P.; Bending, G.D. Contrasting arbuscular mycorrhizal communities colonizing different host plants show a similar response to a soil phosphorus concentration gradient. New Phytol. 2013, 198, 546-556. [CrossRef]

55. Watt-Williams, S.J.; Smith, F.A.; Jakobsen, I. Soil phosphorus availability is a driver of the responses of maize (Zea mays) to elevated $\mathrm{CO}_{2}$ concentration and arbuscular mycorrhizal colonization. Symbiosis 2018, 1-10. [CrossRef]

56. Brundrett, M.; Kendrick, B. The roots and mycorrhizas of herbaceous woodland plants. II. Structural aspects of morphology. New Phytol. 1990, 114, 469-479. [CrossRef]

57. Gavito, M.E.; Olsson, P.A.; Rouhier, H.; Medina-Peńafiel, A.; Jakobsen, I.; Bago, A.; Azcón-Aguilar, C. Temperature constraints on the growth and functioning of root organ cultures with arbuscular mycorrhizal fungi. New Phytol. 2005, 168, 179-188. [CrossRef] [PubMed]

58. Gavito, M.E.; Azcón-Aguilar, C. Temperature stress in arbuscular mycorrhizal fungi: A test for adaptation to soil temperature in three isolates of Funneliformis mosseae from different climates. Agric. Food Sci. 2012, 21, 2-11. [CrossRef]

59. Tammaro, F. Saffron (Crocus sativus L.) in Italy. In Saffron: Crocus sativus L.; Negbi, M., Ed.; Harwood Academic Publishers: Amsterdam, NL, 1999; pp. 53-62.

60. Mollafilabi, A.; Koocheki, A.; Moeinerad, H.; Kooshki, L. Effect of plant density and weight of corm on yield and yield components of saffron (Crocus sativus L.) under soil, hydroponic and plastic tunnel cultivation. Acta Hortic. 2013, 997, 51-58. [CrossRef]

61. Koocheki, A.; Seyyedi, S. How irrigation rounds and mother corm size control saffron yield, quality, daughter corms behavior and phosphorus uptake. Sci. Hortic. 2016, 213, 132-143. [CrossRef]

62. Bayat, M.; Amirnia, R.; Rahimi, M. Phenotypic and genotypic relationships between traits in saffron (Crocus sativus L.) as revealed by path analysis. J. Appl. Res. Med. Aromat. Plants 2017, 5, 33-40. [CrossRef]

63. Geneva, M.; Stancheva, I.; Boychinova, M.; Mincheva, N.; Yonova, P. Effects of foliar fertilization and arbuscular mycorrhizal colonization on Salvia officinalis L. growth, antioxidant capacity, and essential oil composition. J. Sci. Food Agric. 2010, 90, 696-702.

64. Araim, G.; Saleem, A.; Amason, J.; Charest, C. Root colonization by an arbuscular mycorrhizal (AM) fungus increases growth and secondary metabolism of purple coneflower, Echinacea purpurea (L.) Moench. J. Agric. Food Chem. 2009, 57, 2255-2258. [CrossRef]

65. Makhlouf, H.; Saksouk, M.; Habib, J.; Chahine, R. Determination of antioxidant activity of saffron taken from the flower of Crocus sativus grown in Lebanon. Afr. J. Biotechnol. 2011, 10, 8093-8100.

66. Gülçin, I.; Güngör, Ş.; Beydemir, Ş.; Elmastas, M.; İrfan, K. Comparison of antioxidant activity of clove (Eugenia caryophylata Thunb) buds and lavender (Lavandula stoechas L.). Food Chem. 2004, 87, $393-400$. [CrossRef]

67. Chen, Y.; Zhang, H.; Tian, X.; Zhao, C.; Liu, Y.; Jia, L.; Yin, H.X.; Chen, C. Antioxidant potential of crocins and ethanol extracts of Gardenia jasminoides ELLIS and Crocus sativus L. A relationship investigation between antioxidant activity and crocin contents. Food Chem. 2008, 109, 484-492. [CrossRef]

68. Ordoudi, S.; Befani, C.; Nenadis, N.; Koliakos, G.; Tsimidou, M. Further Examination of Antiradical Properties of Crocus sativus Stigmas Extract Rich in Crocins. J. Agric. Food Chem. 2009, 57, 3080-3086. [CrossRef] [PubMed]

69. Karimi, E.; Oskoueian, E.; Hendra, R.; Jaafar, H. Evaluation of Crocus sativus L. stigma phenolic and flavonoid compounds and its antioxidant activity. Molecules 2010, 15, 6244-6256. [CrossRef] [PubMed]

70. Inoue, E.; Shimizu, Y.; Masui, R.; Hayakawa, T.; Tsubonoya, T.; Hori, S.; Sudoh, K. Effects of saffron and its constituents, crocin-1, crocin-2, and crocetin on $\alpha$-synuclein fibrils. J. Nat. Med. 2018, 72, 274-279. [CrossRef] [PubMed]

71. Asdaq, S.; Inamdar, M. Potential of garlic and its active constituent, S-allyl cysteine, as antihypertensive and cardioprotective in presence of captopril. Phytomedicine 2010, 17, 1016-1026. [CrossRef] [PubMed]

72. Amin, S.; Parker, M.; Armbrust, E. Interactions between diatoms and bacteria. Microbiol. Mol. Boil. Rev. 2012, 76, 667-684. [CrossRef] [PubMed] 
73. Del Campo, P.; Carmona, M.; Maggi, L.; Kanakis, C.; Anastasaki, E.; Tarantilis, P.; Polissiou, M.; Alonso, G. Picrocrocin Content and Quality Categories in Different (345) Worldwide Samples of Saffron (Crocus sativus L.). J. Agric. Food Chem. 2010, 58, 1305-1312. [CrossRef]

74. Proestos, C.; Chorianopoulos, N.; Nychas, G.; Komaitis, M. RP-HPLC Analysis of the Phenolic Compounds of Plant Extracts. Investigation of Their Antioxidant Capacity and Antimicrobial Activity. J. Agric. Food Chem. 2005, 53, 1190-1195. [CrossRef] 